Reorganization of biology departments on Berkeley campus

\section{Berkeley, California}

FACULTY and graduate student recruitment is up as the University of California at Berkeley begins an unprecedented reorganization of its biology departments. Ten departments will be dismantled and two created, while two new biology buildings will be put up and a third completely renovated.

Fund-raising for the $\$ 150$-million building project began last year (see Nature 321, 7; 1986) and has raised $\$ 19$ million so far, 122 per cent of the level expected for this point in the drive. In a two-to-one matching agreement, the state has pledged two-thirds of the money needed for the project. The university will raise the other $\$ 47$ million as part of a two-year campus drive seeking $\$ 320$ million for six major projects.

The reorganization, which will redistribute but not enlarge the biology faculty, was conceived in the early 1980 s, after both internal and external review committees concluded that biology at Berkeley was slipping in the national rankings because of outdated laboratories and archaic department divisions.

"Our departments are not congruent with modern biological sciences", said developmental biologist Fred Wilt. For example, developmental biologists are scattered across the campus in five or six different departments, making it difficult for them to act as a group to recruit graduate students.

Such problems are likely to disappear when the new scheme sorts the faculty into departments that accurately reflect their research. Laboratories will be spatially organized into "affinity groups" that share common interests and techniques, to optimize intellectual exchange as well as the use of equipment and facilities.

The biggest reshuffling will be the creation of one large cell and molecular biology department, with 91 members in six divisions: genetics, neurobiology, biochemistry and molecular biology, biophysics, cell and developmental biology and immunology. Faculty may be affiliated with more than one division, and can change divisions as their research interests shift. Graduate students in the department may move among divisions.

The new biology department will have 36 faculty members in the areas of evolutionary, ecological and organismal biology. The 20 -member plant biology department will be an expansion of the present molecular plant biology department, with members coming from the dissolved botany and genetics departments as well.

Many of the more applied departments,

\title{
Confronting natural disasters
}

\section{Washington}

WHEN the largest earthquake in recorded US history hit Alaska in 1964, at magnitude 8.4-8.6 on the Richter scale, this was the result on Anchorage's Fourth Avenue as streets buckled and buildings sank by as much as $4 \mathrm{~m}$. Since then, enormous advances have been made in engineering structures that will reduce casualties and damage from natural disasters, including not just earthquakes but also landslides, tidal waves, windstorms, floods, volcanic eruptions and wildfires.

Prediction of hazards has also come into its own with radar making it possible to track storms more accurately. Some largescale international projects have also proved successful, such as the Pacific Tsunami Warning Center which provides advance warning of tidal waves. But much of what is known about hazard reduction has as yet been applied only in a few parts of the world.

That is the major conclusion of a new report* from the National Academy of Sciences which stresses that "there is a vast opportunity to advance our know-

*Confronting Natural Disasters (National Academy Press, 1987). ledge of hazard reduction if we pool resources". If already available information can reach local officials there are good prospects for improving on a record which has left 2.8 million people dead

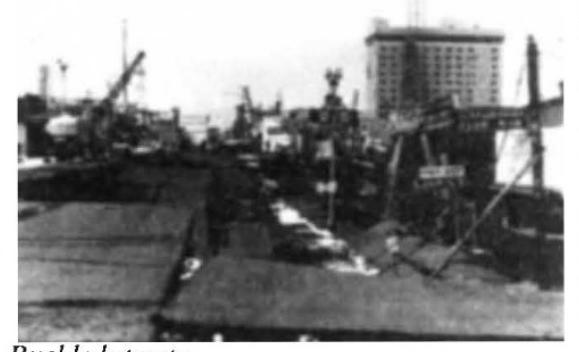

Buckled streets

from natural disasters in the past 20 years.

Towards that goal, the report recommends that an International Decade for Natural Hazard Reduction (1990-2000) be established with the full backing of the United Nations to facilitate cooperative research, technology transfer and training. Leadership could be provided by a strong US programme that, the report says, could "cut impacts of natural hazards at least 50 per cent by the year 2000".

Alun Anderson such as plant pathology and entomology, will remain intact, although some members will join affinity groups containing members of new departments.

Such a major metamorphosis must take place in stages, said Daniel E. Koshland $\mathrm{Jr}$, chairman of the chancellor's committee overseeing the project. The old departments are still operating, but a "shadow government" of new department and division chairmen is already in place, formulating curricula and preparing to take over within a year.

By that time, all the laboratories will be occupied in the first of the two new buildings, the Life Sciences Annex, and the second building will be under construction, with completion planned for 1989.

Renovation of the overcrowded and unsound 55-year-old Life Sciences Building is the final and most ambitious leg of the project, scheduled to take three years, from 1989 to 1992 . Vacant faculty positions may not be filled until the renovation is complete, while laboratory relocation will be a nuisance, but several faculty members say that the intended temporary space will be far superior to what they have now. Marcia Barinaga

\section{India aims at own supercomputer}

\section{New Delhi \& Bangalore}

INDIA will attempt to design and build a parallel processing computing system in three years in a $\$ 50$ million project approved by Prime Minister Rajiv Gandhi.

A new organization, the Centre for the Development of Advanced Computer Technology (CDACT) has been created in Pune, near Bombay. The goal is to develop a parallel computing system with a minimum rating of 50 megaflops and capabilities equivalent to a bottom-level commercial supercomputer.

The new mission implements a recommendation of the Prime Minister's scientific advisory committee headed by Professor C. N. R. Rao. Increasing demands for high-speed computing by Indian scientists, coupled with their failure to obtain a supercomputer of their choice from abroad, have prompted the government to develop its own technology.

CDACT will be answerable to the Department of Electronics but will have considerable autonomy. A spokesman for the department says that the time is ripe for India to enter the field of parallel processing technology because the methods and architecture being developed elsewhere are in their early stages. Assistance will come from many other agencies, including the Indian Institute of Science, the National Aeronautic Laboratory and the Tata Institute of Fundamental Research.

K.S. Jayaraman \& Radhakrishna Rao 